\title{
To Find Or Not To Find: Public Accounting Auditors Versus Governmental Auditors
}

\author{
Leonard Branson, University of Illinois-Springfield, USA \\ Jeffrey L. Decker, Indiana State University, USA \\ Megan Green, Illinois Office of the Auditor General, USA
}

\begin{abstract}
This study examines the impact that the type of auditor (OfficeOffice of the Auditor General (OAG auditor) or CPA firm auditor) has on the number of compliance audit findings reported for select state agencies in a major Midwestern state. In the state studied, The OAG is responsible for conducting compliance audits of government agencies on at least a biennial basis. These audits are either performed by the Auditor General's state auditors or by Certified Public Accounting (CPA) firms under contract to the OAG. A sample of agencies with audits that were sometimes performed by CPA firms and sometimes by OAG auditors was chosen. A statistical analysis concluded the number of compliance audit findings reported by OAG auditors was significantly higher than the number of compliance audit findings reported by CPA firm auditors, for the same set of state agencies.
\end{abstract}

Keywords: Audit; Auditors; Compliance; Findings; Governmental Auditing; Public Accounting

\section{INTRODUCTION}

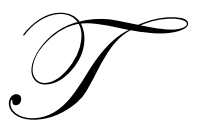

op level executives of all organizations, public and private, are required to maintain effective internal control of their organizations. Experiences throughout history have intensified the focus on the need for adequate internal controls in all organizations. In the past 20 years alone, we have witnessed organizations such as Pharm-Mor (retail drug store), Xerox, Enron and others falsify their financial statements, resulting in billions of dollars in shareholders wealth being lost. These shareholders include pension funds such as California's (Calpers) group which have put the retirement benefits of millions at risk while increasing the financial burden for millions of taxpayers. But these publicly traded corporations are not the only ones with problems. States across the USA have resorted to significant blurring of compliance/noncompliance with state constitutions and federal regulations in their attempt to muddle through the current recession without significant cutting of state programs or increasing taxes. Without proper guidelines to follow, executives, whether working for private firms or the government will look for ways to minimize the negative impact of problems facing their organizations by changing the rules under which they operate. Holding these executives and others accountable with a written, established internal control program is the most efficient and effective way to safeguard all stakeholders, present and future. The Foreign Corrupt Practices Act of 1977 and the Sarbanes Oxley Act of 2002 put significant teeth into the requirement for profit seeking publically traded organizations to not only implement adequate internal controls, but to audit internal control on a regular basis. Management is required by law to make assurances that internal controls in their organizations are functioning effectively. Governmental entities are equally required to maintain adequate internal controls as evidenced by the United States General Accounting Office's Standards for Internal Control in the Federal Government (GAO, 1999). In addition, Federal, State and Local governmental units are required to have annual audits. These audits are to be conducted in accordance with generally accepted government auditing standards (GAGAS), or the "Yellow Book". Auditors are required to report not only on the financial statements of the governmental unit, but like their private sector counterparts, they are required to report on the internal control structure of the entity. 
The importance of internal control has been summarized by Robert Mueller's "Brinks Modern Internal Auditing" as:

"Being implemented by management to provide reasonable assurance for:

- $\quad$ Reliable financial and operational information

- $\quad$ Compliance with policies and procedures plans, laws, rules, and regulations

- $\quad$ Safeguarding of assets

- $\quad$ Operational efficiency

- $\quad$ Achievement of an established mission, objectives and goals for enterprise operations and programs

- Integrity and ethical values"

These areas affect the vast majority of stakeholders in any organization and underscore the degree to which internal control has grown from a conceptual idea to a concrete set of steps to take to protect various stakeholders.

Compliance audits are extremely important for state agencies because they assure citizens, legislators and other interested parties that the agency is performing its statutory obligations, and is operating within all applicable state and federal laws and regulations, as well as all relevant contracts and policies. All state agencies are created by state statute, and they receive their operating authority and financial resources through the legislative process. Agencies are charged with the enforcement/enactment of specific laws in order to achieve given social objectives. The policies, procedures, rules and regulations which the agency uses to achieve the objectives of the legislation are required to be approved by the Joint Committee on Administrative Regulation (JCAR). Many of the state agencies receive federal money, and in exchange are obligated to operate within the guidelines established by the Federal Government. Auditors are required to approach their work with a healthy skepticism, which means that they should consider that agencies may have motives to falsify information if they are not held accountable, by a compliance audit, to the state and federal regulations applicable to the organization. Compliance audits provide assurance that agencies are in compliance with the relevant laws, regulations, etc. When an agency is not in compliance with a relevant law, regulation, contract, etc., the auditor will report the non-compliance as a "finding" in the compliance audit report. At the state level, the state OAG is responsible for Performance Audits, Financial Audits, Compliance Audits, and Information Systems Audits. The OAG provides agencies with specific recommendations to ensure full compliance with State statutes, rules, and regulations, and reviews compliance with federal statutes, rules and regulations for those agencies subject to the Federal Single Audit Act of 1984.

Every State agency must undergo a compliance audit examination at least once every two years. The Auditor General is responsible for the completion of these compliance audits, and either performs them with OAG staff auditors or contracts with CPA firms. Contracting with CPA firms has become more expensive for the State. As a result, the Illinois OAG has instituted a strategy of reducing the number of audits contracted with CPA firms and increasing the number of audits performed by OAG auditors. Consequently, a number of agencies that used to be audited by CPA firm auditors have changed to OAG auditors. This study looks at a sample of agencies that had compliance audits conducted by both CPA firm auditors and then by OAG auditors between 2000 and 2009; examining the relationship between the type of auditor performing compliance audits of State agencies and the number of findings in the compliance audit reports.

\section{LITERATURE REVIEW}

Article VIII, Section 3 of the Illinois State Constitution of 1970 establishes the duties and responsibilities of the Office of the Auditor General. The constitution states, "The Auditor General shall provide by law for the audit of the obligation, receipt, and use of public funds of the State." (Illinois General Assembly, n.d.). The General Assembly appoints the Auditor General to a ten year term. The Auditor General is responsible for the implementation of the Illinois State Auditing Act, and has jurisdiction over all state agencies. All audits are performed under Generally Accepted Auditing Standards (GAAS) (Illinois General Assembly, n.d.).

The Illinois Auditor General is a constitutional officer and is responsible for performing audits of State funds. Audit reports are made available to the Legislature, Governor, and management of state agencies, media, and 
the public (Illinois Auditor General, n.d.). Because these reports are publicly available, they help keep State agencies accountable to the people of the state. State agencies know it will reflect badly on them if an audit report is issued with numerous findings, and so they will be more likely to prevent or correct problems within the agency. Additionally, the Illinois Legislature can review these reports and as a result can make more informed decisions about how to appropriate funds and set goals for State programs (Illinois Auditor General, n.d.). When audit tests reveal instances of noncompliance in areas such as travel expenditures, telecommunications expenditures, accounts receivable, and applicable statutory mandates, the auditors write findings describing what was found. The reports also provide recommendations to agencies so that they may comply with State statutes, rules, and regulations (Illinois Auditor General n.d.). According to the State Auditing Act, the Auditor General has the authority to contract with CPA firms licensed in the state to carry out audits. CPA firms of all sizes perform audits as "Special Assistant Auditors" to the auditor general (Illinois General Assembly n.d.).

The United States Government Accountability Office (GAO) had concerns about the quality of governmental audits performed by CPA firms. In 1986, the GAO reviewed the quality of CPA firm audits of federal programs, and found that 34 percent of the audits did not comply with auditing standards. The GAO also had a problem with CPA firms not maintaining sufficient audit work papers (U.S. Government Accountability Office n.d.).

Jakubowski (2008) studied a sample of county component units in Michigan to determine if there was a relationship between reportable conditions and noncompliance findings and type of auditor (either independent CPA firm or state auditor). The study included every component unit in Michigan that filed a report with the Michigan OAG, resulting in a sample size of 27. Eighteen component units were audited by CPA firms, and nine component units were audited by state auditors. The study found that state auditors report more noncompliance findings than independent CPA firms, but that both CPA firms and state auditors reported few reportable conditions. According to the study, the difference in number of findings may be because state auditors lack a profit motive, and therefore may be more willing to spend more time and effort gathering audit evidence (Jakubowski 2008).

A study by Rubin focused on the differences in audit fees and audit timeliness between state auditors and independent public accountants for audits of 156 municipalities in Ohio with a population over 10,000 (Rubin, 1992). The results indicated there were significant differences in the fees charged by state auditors and independent public accountants. The study also found that independent public accountants were more likely to submit timely audit reports than state auditors. A reason for this is that independent CPA firms have more resources and more flexibility within their resources than state auditors. CPA firms can provide a fast but expensive audit, while state auditors can provide a less expensive audit that is not as timely. The Rubin (1992) study also noted that larger cities are more likely to use a state auditor and that the relationship between the total debt of a municipality and type of auditor was not significant. Additionally, cities governed by a manager were more likely to request that audits be performed by independent CPA firms (Rubin, 1992).

A 2008 British study by Ballantine, Forker, and Greenwood examined the English National Health Service (NHS) Trusts. The NHS allows departures from British GAAP in order to achieve financial breakeven. These departures have been criticized by the Audit Commission, the British agency in charge of regulating auditors. The study examined the relationship between abnormal accruals and the achievement of financial breakeven. Additionally, the study tested to see if there was a relationship between the type of auditor performing the audits of the trusts and abnormal accruals. The Ballantine (2007) study classified auditors into three categories: AC, Big 3, and second-tier auditing firms. AC is the Audit Commission, which employs government auditors and is responsible for appointing auditors to NHS audits and maintaining auditor independence and audit quality. The Big 3 auditing firms are KPMG, Deloitte, and PwC. Second-tier auditors are smaller audit firms in England. The study found that abnormal accruals are used to achieve financial breakeven. Additionally, the study found no relationship between abnormal accruals and type of auditor (Ballatine, Forker, \& Greenwood, 2008).

\section{METHODOLOGY}

The purpose of the present study is to determine if there is a relationship between the type of auditor (either CPA firm auditor or State Auditor) and the number of compliance findings reported in audit reports of State 
government agencies. The research question proposed is:

Does the type of auditor affect the number of compliance audit findings for State government agencies?

Based on prior research (Jakubowski 2008), it would be expected that State (OAG) auditors would report more findings than CPA firm auditors in compliance audits of state government agencies.

The research hypothesis for this study is:

H1 $1_{\mathbf{a}}$ : Compliance audits of Illinois State government agencies conducted by State auditors will result in more findings than compliance audits of state agencies conducted by CPA firms.

The Office of the Auditor General audits many diverse agencies. Agencies vary in terms of size, type of appropriations, federal funding, number of laws that apply the complexity of policy differences, number and complexity of contracts, etc. Because of the significant number of potential compliance violations introduced by the above factors, and because all agencies differ on several of them, the researchers decided to only look at agencies that had audits historically performed by CPA firms and then switched to having OAG auditors perform the compliance audit. There were 24 agencies that were audited by both CPA firm auditors and OAG auditors between 2000 and 2009. Because each agency is being compared to itself, differences between state agencies have been controlled.

For this study the researchers looked at compliance audit reports only. Financial audit reports and reports that were both financial and compliance were not considered in this study. The population is all the state agencies that had compliance audits performed by both OAG auditors and CPA firms during the period of Fiscal Year 2000 through Fiscal Year 2009. The researchers collected the data from Report Digests on the OAG's website.

The dependent variable in the present study is the number of findings in compliance audits of state agencies as reported in the Report Digests. The dependent variable could range from 0 to any real integer, and the researchers consider it to have face validity. The independent variable is the type of auditor performing the audit, either a CPA firm auditor (0) or an OAG auditor (1).

\section{RESULTS}

Agencies that changed from CPA firm auditors to governmental auditors between 2000 and 2009 were identified. Three years of data before the change and three years of data after the change were collected. The average number of compliance findings before the change in auditor and the average number of findings after the change in auditor was calculated. A paired samples $t$-test was performed on the data to determine if the there was a significant difference in the number of compliance findings before (CPA firm auditor) and after (OAG auditor) the change in auditor. The paired samples $t$-test as a pre-post type of test was appropriate because we were evaluating the exact same group before and after an event (change in auditor).

The data was analyzed using the paired samples t-test in SPSS. There was a significant difference between the CPA Mean $=2.36$, and the OAG Mean $=5.56, t(23)=-3.71, p=.001$. The important point is that the OAG auditors discovered and reported significantly more compliance findings than the CPA firm auditors. The research hypothesis can be supported.

\section{CONCLUSION}

This study looked at the same state agencies when they were audited by CPA firm auditors and governmental (OAG) auditors. The conclusion reached in this study, that governmental auditors report more compliance audit findings than CPA firm auditors, supporting Jakubowski's (2008) research. Jakubowski (2008) found that state auditors report significantly more noncompliance findings than CPA firm auditors. The Jakubowski study selected county government entities in Michigan, while this study looked at state agencies in Illinois. In this study, governmental auditors did identify and report more internal control compliance findings than CPA firm auditors. 
Prior research indicates that CPA firm auditors submit more timely reports than governmental auditors (Rubin 1992). Timeliness of reporting could very well be due to the profit objective of the CPA firms and their employee auditors need to meet a standard in billable hours. The same pressure might prevent them from finding noncompliance issues and reporting them. The governmental auditors might have more time to develop a better understanding of the applicable laws, regulations, policies, contracts, etc. and to test for compliance with them. The issue of lack of reportable findings may indicate inadequate audits. If an auditor fails to collect sufficient, competent evidential matter then the auditor would not find the reportable noncompliance. It may be difficult for the CPA firms to substantiate the claim that they are following the required auditing standards.

The Sarbanes-Oxley Act was a reaction to the concerns the public had with the quality of the work of independent CPAs in the private sector. The GAO $(1986,1989$, and 2007) has repeatedly expressed concern over the quality of audits performed by CPA firm auditors, including a finding that in some cases the audits of the CPA firm auditors were not conducted according to GAGAS.

The sample in this study was 24 agencies in a single state government. The results of this study cannot be generalized to all governmental units or states. Another important limitation in this study is the fact that during the time of this study, 2000-2009, a new administration was elected in 2002. The new administration may have created a culture that led to widespread disregard for compliance with laws, regulations, contracts, policy, etc. In addition, during this time the internal audit function of state government was centralized, and this structural change could have lead to more actual noncompliance behaviors and consequently to more reportable noncompliance findings. The state audit function has been closely related to public accounting concerning the types of auditors used for various tasks and turnover issues relating to auditors moving out of the audit function and into more general accounting positions. Future research examining the impact of the change in administration, and the centralization of the internal audit function on the effectiveness of internal controls in state agencies, would increase our understanding of how these issues may impact the effectiveness of governments' audit/compliance functions.

\section{AUTHOR INFORMATION}

Leonard Branson is a Professor of Accounting at the University of Illinois-Springfield. He is a CPA and active in numerous organizations locally and nationally. E-mail: lbran1@uis.edu

Jeffrey L. Decker is an Associate Professor of Accounting at the Indiana State University. He is a CPA as well as a CIA. E-mail: jeffrey.decker@indstate.edu

Megan Green is an auditor for the state of Illinois. She is a graduate of the University of Illinois-Springfield. E-mail: megreen2@uis.edu

\section{REFERENCES}

1. Ballatine, Joan, John Forker, and Margaret Greenwood. "Public and Private Sector Auditors and Accruals Quality in English NHS Hospital Trusts." The British Accounting Review, 2008: 28-47.

2. Illinois Auditor General. Illinois Office of the Auditor General. http://www.auditor.illinois.gov/About/description.asp (accessed June 10, 2010).

3. $\quad$ "Illinois Office of the Auditor General." Public Documents. http://www.auditor.illinois.gov/Other-PublicDocuments/QuarterlyReport/10-2nd-Quarterly-Rpt.htm (accessed June 10, 2010).

4. $\quad$ "Illinois General Assembly." Constitution of the State of Illinois. http://www.ilga.gov/commission/lrb/conmain.htm (accessed June 15, 2010).

5. Illinois General Assembly. Illinois Compiled Statutes. http://www.ilga.gov/legislation/ilcs/ilcs5.asp?ActID=466\&ChapAct=30\%26nbsp\%3BILCS\%26nbsp\%3B5 $\% 2 \mathrm{~F} \&$ ChapterID $=7 \&$ ChapterName=FINANCE \&ActName=Illinois+State+Auditing+Act\%2E $($ accessed June 15, 2010).

6. Jakubowski, Stephen T. "Local Government Audits: A Look at Audit Findings adn Differences Related to the Type of Auditor." Municipal Finance Journal, 2008: 77-89. 
7. Moeller, Robert R. (2009) Brink's Modern Internal Auditing ( $7^{\text {th }}$ ed.). New Jersey: John Wiley \& Sons, Inc.

8. Rubin, Marc A. "Municpal Selection of State or External Auditor for Financial Statement Audits." Journal of Accounting and Public Policy, 1992: 155-178.

9. U.S. Government Accountability Office. U.S. Government Accountability Office. http://archive.gao.gov/d13t3/129564.pdf (accessed March 28, 2010).

10. United States General Accounting Office. 1999. "Standards for Internal Controls in the Federal Government" GAO/AIMD-00.21.3.1.

11. United States Government Accountability Office. 2007. "Single Audit Quality-Actions needed to Address Persistent Audit Quality Problems". GA08-213T. 